\title{
Mechanical Property of 9 Years Old Thinning of Teak Plantation in Thailand
}

\author{
Somchai Seviset ${ }^{1}$, Thanate Piromgran ${ }^{1}$, Udomsak Saributr ${ }^{1}$, Ratthai Porncharoen ${ }^{1}$, Kananke Raerai ${ }^{1}$ and Sittichai \\ Charoensettasilp ${ }^{2}$ \\ ${ }^{1}$ Faculty of Industrial Education, King Mongkut's Institute of Technology Ladkrabang, Bangkok 10520, Thailand \\ ${ }^{2}$ Faculty of Science, King Mongkut's Institute of Technology Ladkrabang, Bangkok 10520, Thailand
}

\begin{abstract}
Based on the study of the conditions and problems of thinned teak in Thailand it's with findings that thinned teak or so called thinning for distance clearance being with small stems and can be sold at low price. thinned teak was with mechanical property different with teak from natural forest with age over 30 years old with the results of most of the tests were with findings that the values of the mechanical property of teak from natural forest with age over 30 years were more valuable than the values of the mechanical properties of thinned teak with exception on Standard Test Method for Tensile and Cleavage Test of Timber which thinned teak was with more value than teak from natural forest with age over 30 years old. For guidelines on market value added for thinned teak can be made by producing to use in the context of the design of household goods made of wood as the guide for resolution of problems and creation of artistic work pieces household goods made of wood.
\end{abstract}

\section{Introduction}

Teak/teakwood has its origin in Southern areas of India, Burma, Thailand, Laos (the part adjacent to Thailand North Region) and Indonesia. In Thailand teak mostly grows up in Five Kinds Unassorted Forest or Miscellaneous Forest in the North. Teak is fond to grow in mountainous areas or on a plateau conditional to well water drainage and non-flood, which can be a mixture of crumby soil with sand or soil with very much depth especially soil derived from limestone which is broken decayed rotten turning into a depth of crumby soil strata which will help teak to grow very well. Teak usually grows in a cluster of pure teak as a dump of teak or may grow mixing with other miscellaneous woods such as red Pterocarpus, Ormasia Dalbergia, Lagerstroemia etc.[1]

In Thailand teak generally is with scattered growth according to the nature in miscellaneous forest. Teak is wood of high economical value, in the past, it used to be export goods making top income revenue to Thailand second to only rice. Later teak from natural forests in Thailand was with reduced volume and became with higher price. Additionally, there are increasing trends of using teak from forest plantations therefore there is also increasing growth of teak to which Thailand Department of Forest has promoted the private sector and agriculturists/farmers to grow economical wise forest plantations with finding that teak is the kind of wood which the people are fond of growing but the administration in the past growers faced the problems of growing in unsuitable areas, lacking of knowledge and understanding on growing, and bad management, therefore, upon thinning there was a lot of teak scraps to be thinned, thereby, has made some growers turning to grow plants with short-term return instead. [2]

The production of teak for thinning or a large number of teak being thinned for testing of mechanical quality/properties of wood is another variable which is used to specify the quality of wood which wood standard tests are carried out by the Office of Building Control and Inspection, Department of Public Works \& Town Plan of Thailand B.E. 2008 which has stipulated the Test Standards as follows.

MorYoPor. 1221-51: Standard Test Method for Compression Perpendicular to Grain;

MorYoPor. 1222-51: Standard Test Method for Compression Parallel to Grain;

MorYoPor. 1223-51: Standard Test Methods for Direct Moisture Content Measurement of Wood;

MorYoPor. 1224-51: Standard Test Method for Static Bending of Timber);

MorYoPor. 1225-51: Standard Test Method for Tensile and Cleavage Test of Timber;

MorYoPor. 1226-51: Standard Test Method for Shear Test of Wood Parallel to Grain;

MorYoPor. 1227-51: Standard Test Method for Specific Gravity to Grain;

The foregoing Standard Tests will make us know the various properties of teak thinned for distance clearance which, based on a collection of research works dealing with teak thinned for distance clearance it's found that the production of teak thinned for distance clearance was 
still not with sufficient data to be guidelines or guidance for study for exploitation on various aspects and to make added value to growing agriculturists/farmers.

This research article, therefore, would like to make presentation of making added value of teak thinning or teak thinning for distance clearance of 9 years old by testing the mechanical property of the wood as primary information on the development and promotion on usage of thinned teak for production of optimal usage as well as being potentiality development and making added economical value resulting the interest to Thai agriculturists/farmers next.for thinning or a large number of teak being thinned for testing of mechanical.

\section{Literature review physical properties of teak in Thailand}

In Thailand there is only one kind of Teak but may be called in other names such as Gold/Thong Teak, Stone/Hin Teak, Buffalo Shit/Ki Kwuai Teak following the nature of the wood patterns or colors which are different which may be from factors of different environments such as rain volume, soil type and mineral elements or natures of making use of teak taking into consideration based on the colors of the wood pulp, decoration, hardness and tensility of wood pulp into 5 categories of:

Thong/Gold Teak. The wood pulp is gold brown color, straight grain with ease for furnishing;

Hin/Stone Teak. The wood pulp is brown or pale with ease for furnishing;

Yuak/Soft Teak. The wood pulp is light brown or pale and is with ease for furnishing;

Khai/Egg Teak. The wood pulp is dark brown mixed with yellow, having the content of fat and thus making it difficult for furnishing and coating/painting.

Ki Kwuai/Buffalo Shit Teak. The wood pulp is a mixture of gree with brown, dark brown appearing as blurred coloring.

Thinning. Bunvong Thaiutsa et al. (1992) said that thinning is a necessary forestry practice for forestry management all this irrespective whether thinning for sale will be cost-efficient or not as a by-product of the forestry plantation growing whose genuine philosophy of thinning is for the improvement of the growth of remaining plantation. Thinning is virtually cutting out of partial of wood for teakwood to grow more dense for making the remaining teakwood grow up to larger size to which the size of the wood is normally related direct with its top housing and root housing i.e. if the top housing expands more then the three may grow with larger size. Growing threes must be made with density on the beginning for the trees to compete the height of their stem, straight stem, not much branching saving branch cutting. Teakwood growth may start with distance clearance of 3 x 3 meters. After teak growth for another period teak top housing will start to be close together again, growth will not increase thus necessitating another thinning. Leaving this alone will cause natural competition by teakwood, there is scrambling or competition for water and food causing partial of the trees to die. Part of teakwood will stabilize or stop growing thereby larger size of wood to derive will take longer time and not cost-efficient. Teakwood growth should be with the first thinning upon or when the density starts, top housing scrambling too close together prevents growth not to increase which is depending on the area condition, growing clearance distance, growth duration, maintenance. Generally teakwood will start to be dense at the age of approximately 6-10 years which will necessitate thinning then. Afterwards, let the teakwood grow until their top housings are scrambling close together again and then continue with the 2 nd thinning at the age of about 15-22 years. For teakwood growth the first thinning will be with small size of teakwood, low price, most growers of teak plantation forestry normally will not do thinning despite the fact that teakwood trees are very dense and thereby causing the overall growth of teakwood although inability to make sale of the wood cost-efficiently. It may be necessary for the growers of the teak plantation forestry to make thinning by taking the wood for self-usage. In respect of the methods of thinning these are comprises of :

1) Systematic thinning is thinning systematically or thinning one row skip one row or thinning one tree and skip another tree;

2) Selective thinning is selecting to thin larger sized tree or smaller sized tree out. For large scale teak plantations systematic thinning will help facilitation of thinning. For teak plantations with small size area if there is existence of different growth the method of selective thinning should be chosen with the first thinning to choose to screen small sized with bad appearance out leaving teakwood trees with nature of well growth because trees with good growth can grow up to be larger trees betters thereby making the forestry plantation with higher productivity per Rai, cost-efficient on the last thinning round better with teak for sale at good price and mostly needed of the market demand, i.e. with age of more than 15 years old, with circumference at the height of 1.30 meters of more than $60 \mathrm{~cm}$.'s upwards. For some areas which teak growers fail to carry out thinning teakwood will grow densely, scrambling and growth is not even. There are both large and small trees, on the first thinning will then necessitate to choose small trees for thinning and leaving larger trees to remain. Growers' problems on thinning include such as:

1) Market limitation and on the exploitation of the first stage thinning, trees are of small sizes and low price, considered as discarded teakwood.

2) The problems on buyer's selection to buy. Growers let the medium buyers to go in for selection to thin, by selecting to thin only large sized trees out, leaving only small sized unhealthy trees. Their growth will then be slow thereby making the productivity to get in the future low and not cost-efficient

3) Growing agriculturists/farmers are lacking of knowledge and understanding about the relation of the growth of the trees with the density of the tress thereby rendering them not taking the importance of thinning leaving the forestry plantations to grow densely and with competition for nutrients. 


\section{Mechanical properties of teak test in Thailand}

The Department of Public Works and Town Plan has established various standards e.g. standard of material specification, method of test standard, standard of design, construction supervision standard, standard for installation and inspection, standard for maintenance for instances, in order of establishment of safety on lives and properties belonging to the population as well as provision of academic support to local administration organizations, various public offices both centrally and in the regions whose test standards are listed as follows:

1. Standard Test Method for Compression Perpendicular to Grain.

This Standard Test covers the study of behaviors and determination of mechanical property of wood under compression perpendicular to grain to determine required values of Modulus of Elasticity, Elastic Force at Proportional Limit, yield strength of wood at offset distance of $0.05 \%$.

Standard Test Method for Static Bending of Timber wood at offset distance level of $0.05 \%$

This standard uses SI (International System Units) as principle and uses the value of unit conversion of 1 kilogram force equal to 9.806 newton.

Preparation of Sample Pices. The sample preparation of Dressed Timber is required by the wood must be in the good order condition with no cracks of the size $50 \times 50 \times 150 \mathrm{ml}$. each kind of 3 pieces [3]

2. Standard Test Method for Compression Parallel to Grain.

This standard test covers the study the behaviors and determination of mechanical properties of wood under the pressure parallel to grain to determine the required value of $0.05 \%$ and annihilation compression of the wood, as well as the study of the nature of failure of the wood upon reaching the failure point.[4]

This standard uses SI (International System Units) as principle and uses the value of unit conversion of 1 kilogram force equal to 9.806 Newton.

Preparation of Sample. The sample preparation of Dressed Timber of the size $50 \times 50 \times 150 \mathrm{ml}$. total of 3 pieces is required by the wood pieces must be in the good order condition with no cracks along the length and the cross section profile shall be perpendicular so that the compression scattered on the cross section profile evenly.[5]

3. Standard Test Methods for Direct Moisture Content Measurement of Wood

This standard test covers determination for the volume of humidity of the wood with the method of drying. This Standard test used SI (International System Units) as principle.

The standards referred to in this standard is comprised of the Department of Public Works \& Town Plan Standard MorYorPhor. 1104: Woodwork Standard.

Preparation of Sample Pieces. The sample preparation of Dressed Timber, which is uncoated with chemical of total of 3 pieces with cross section profile size of $50 \times 100$ $\mathrm{ml}$. with length parallel to grain $25 \mathrm{ml}$. [6]
4. Standard Test Method for Static Bending of Timber.

This Standard Test Method covers determination of mechanical property of wood with the test of bending resistance force for observation of wood behaviors, nature of wood rupture at point of failure on being acted upon and consideration for values required i.e. Stress in Outer Fiber at Proportional Limit, Modulus of Rupture, Modulus of Elasticity, Maximum Shearing Stress, Modulus of Resilience, Type of Failure.

This standard uses SI (International System Units) as principle and uses the value of unit conversion of 1 kilogram force equal to 9.806 Newton.

Preparation of Sample Pieces. A preparation of Dressed Timber must be made of total of 3 pieces free from buds or defects in good working order condition with no traces of cracks of the size 50x50x760 ml. [7]

5. Standard Test Method for Tensile and Cleavage Test of Timber.

This standard test covers determination of mechanical property of wood upon tensility force perpendicular to grain and failure resistance of the wood.

This standard uses SI (International System Units) as principle and uses the value of unit conversion of 1 kilogram force equal to 9.806 Newton.

Preparation of Sample Pieces. Preparation must be made for Dressed Timber for test of tensility of wood and test on wood failure resistance of 3 pieces of each kind with natures/appearance and size as stipulated in the Form. [8]

6. Standard Test Method for Shear Test of Wood Parallel to Grain

This Standard Test covers determination of ability to receive the shears of wood parallel to grain of wood.

This standard uses SI (International System Units) as principle and uses the value of unit conversion of 1 kilogram force equal to 9.806 Newton.

Preparation of Sample Pieces. Preparation of sample pieces of Dressed Timber of 3 pieces free from buds or defects in good working condition, no traces of crack of $50 \times 50 \times 63 \mathrm{~m}$. size with cross section profile of the size $50 \times 50 \mathrm{ml}$. [9]

7. Standard Test Methods for Specific Gravity of Wood.

This standard test cover determination of the value of specific gravity of the wood in the normal condition and in the dried condition. This standard test uses SI (International System Units) as primary principle.

Preparation of Sample Pieces. A preparation of sample pieces of Dressed Timber with the size according to the length to parallel grain of $25 \mathrm{ml}$. of 3 pieces or in case of flat plank sheet to be with space of $75 \times 120 \mathrm{ml}$. ( $3 \times 6$ inches) total of 3 pieces.

As for the Structural Elements should be cut of wood pieces to be with minimum length of $450 \mathrm{ml}$. (18 inches) and then produce for preparation of sample pieces for prevention of loss of humidity at the end of the sample pieces. [10]

\section{Research objectives}


1. To study the condition and problems of thinned teak (teak thinned for distance clearance of 9 years old) in Thailand;

2. To make an examination of the mechanical properties of thinned teak (teak thinned for distance clearance of 9 years old) in comparison with team from natural forest;

3. As a guidance for making market value added thinned teak (teak thinned for distance clearance of 9 years old).

\section{Research hypothesis}

Thinned teak (teak thinned for distance clearance of 9 years old) was with mechanical property not different from teak from natural forest.

\section{Research methodology}

1. Study for Primary Information with the research of data concerning teak, the properties of wood material, quality test, and mechanical properties of thinned teak and other relevant data, relating researches, books, and textbooks for instances by making studies from libraries, various media and theses in order to obtain primary data and basic data of the research.

2. Study Wood Test Standards and methods of tests of mechanical test of wood in preparation for tests on thinned teak;

3. Preparation of teak thinned (teak thinned for clearance of 9 years old) to be in accordance with the forms stipulated ready for the tests;

4. Testing thinned teach and make result analysis;

5. Comparison of mechanical properties of teak thinned with mechanical properties of teal from natural forest;

6. Conclusion and debate of the research results.

1

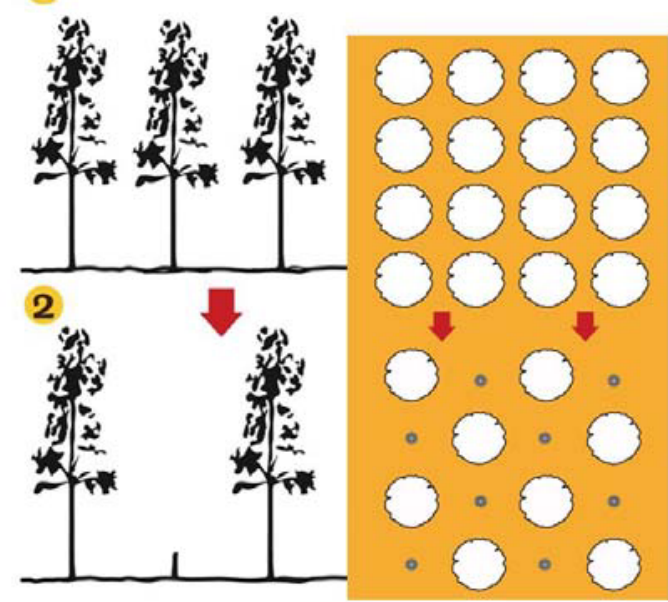

Figrue 1. Demonstrating preparation of sample for testing mechanical properties of thinned teak (teak thinned foe distance clearance of 9 years old).

\section{Material and mechanical properties test}

When teakwood is during the age of 7-15 years old there must be thinning for distance clearance because teak top housing are closely scrambling thereby rendering growth to be slowed down thus necessitating to make thinning for distance clearance to reduce competition of light and nutrients amongst teakwood trees (Fig. 1) teak of which obtained from thinning for distance clearance is with little value and low price when compared with teak from general natural forest thereby emerging the research concerning thinned teak for making Market Value Add.

On this research the Author has produced teak thinned for preparation as samples for testing of mechanical properties of thinned teak by making preparation according to the instruments used for measurement of the mechanical properties as provided for by each instrument such as on standard test method for compression perpendicular to grain the sample preparation of dressed timber must be made with dressed timber and the wood must be in the good order condition with no cracks of the size $50 \times 50 \times 150 \mathrm{ml}$. each kind of 3 pieces as shown in Fig. 2.

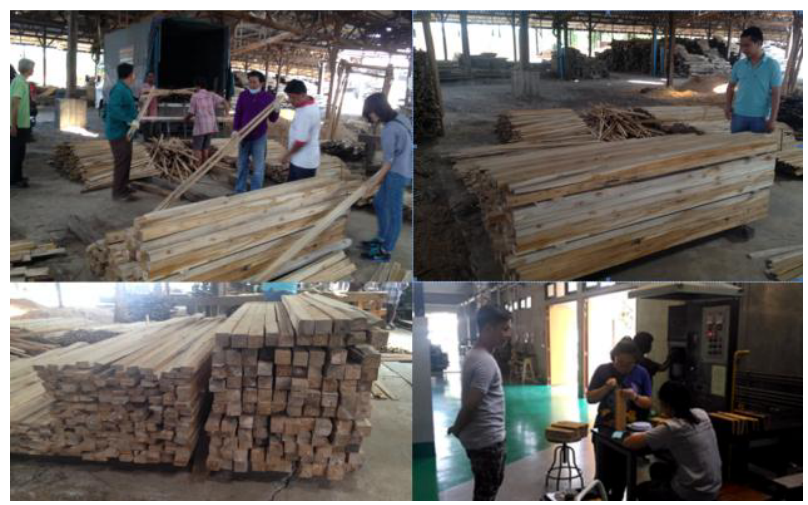

Figure 2. The sample preparation of dressed timber.

After making preparation of the samples for testing of the mechanical properties then the tests themselves would be carried out including Standard Test Method for Compression Perpendicular to Grain, Standard Test Method for Compression Parallel to Grain, Standard Test Methods for Direct Moisture Content Measurement of Wood, Standard Test Method for Static Bending of Timber, Standard Test Method for Tensile and Cleavage Test of Timber, Standard Test Method for Shear Test of Wood Parallel to Grain, Standard Test Methods for Specific Gravity of Wood.

After the tests the Author took the information obtained from the tests for data analysis with the method of descriptive statistics with determination of the mean of each method of test.

\section{Research results}

On this research the mechanical properties of teak from natural forest with age over 30 years or more as teak from natural forest for comparison with thinned teak in which the values of figures of each test can be demonstrated in Table 1.

From Table 1. It's found that the test of the mechanical property of thinned teak when the values of data obtained in each test to determine the average (mean) 
and make comparison with the test value of each test of teak from natural forest with age over 30 years old were with results according to Table 2 .

Table 1. Demonstrating the unit (s) and interpretation result of tests of each subject matter.

\begin{tabular}{|l|c|c|}
\hline \multicolumn{1}{|c|}{ Test } & Unit & $\begin{array}{c}\text { Interpretation } \\
\text { Result }\end{array}$ \\
\hline $\begin{array}{l}\text { Compression } \\
\text { Perpendicular to Grain } \\
\text { Resistance }\end{array}$ & $\mathrm{MPa}$ & $\begin{array}{l}\text { Higher } \\
\text { (Good) }\end{array}$ \\
\hline $\begin{array}{l}\text { Compression Parallel to } \\
\text { Grain Resistance }\end{array}$ & $\mathrm{MPa}$ & $\begin{array}{l}\text { Higher } \\
\text { (Good) }\end{array}$ \\
\hline $\begin{array}{l}\text { Shear Parallel to Grain } \\
\text { Resistance }\end{array}$ & $\begin{array}{c}\text { Percentile } \\
(\%)\end{array}$ & Less \\
\hline $\begin{array}{l}\text { Shear Parallel to Grain } \\
\text { Resistance }\end{array}$ & $\mathrm{MPa}$ & $\begin{array}{l}\text { Higher } \\
\text { (Good) }\end{array}$ \\
\hline $\begin{array}{l}\text { Shear Parallel to Grain } \\
\text { Resistance }\end{array}$ & $\mathrm{MPa}$ & $\begin{array}{l}\text { Higher } \\
\text { (Good) }\end{array}$ \\
\hline $\begin{array}{l}\text { Shear Parallel to Grain } \\
\text { Resistance }\end{array}$ & $\mathrm{MPa}$ & $\begin{array}{l}\text { Higher } \\
\text { (Good) }\end{array}$ \\
\hline $\begin{array}{l}\text { Specific Gravity } \\
\text { Determination }\end{array}$ & - & $\begin{array}{l}\text { Higher } \\
\text { (Good) }\end{array}$ \\
\hline
\end{tabular}

Table 2. Demonstrating the test values of each test of thinned teak in comparison with teak from nature forest with age over 30 years old.

\begin{tabular}{|l|c|c|}
\hline \multicolumn{1}{|c|}{ Test } & $\begin{array}{c}\text { Thinned } \\
\text { Teak }\end{array}$ & $\begin{array}{c}\text { Teak with } \\
\text { Age over } \\
30 \text { years }\end{array}$ \\
\hline $\begin{array}{l}\text { Compression Perpendicular to } \\
\text { Grain Resistance }\end{array}$ & 8.00 & 22.92 \\
\hline $\begin{array}{l}\text { Compression Parallel to Grain } \\
\text { Resistance }\end{array}$ & 32.00 & 35.70 \\
\hline Grain Humidity Determination & 0.20 & 0.20 \\
\hline Static Bending Resistance & 7,412 & 7,996 \\
\hline $\begin{array}{l}\text { Tensile and Cleavage } \\
\text { Resistance }\end{array}$ & 92.24 & 63.00 \\
\hline $\begin{array}{l}\text { Shear Parallel to Grain } \\
\text { Resistance }\end{array}$ & 11.28 & 13.00 \\
\hline Specific Gravity Determination & 0.52 & 0.60 \\
\hline
\end{tabular}

Note ; Tests with more values are shown in bold letters.

\section{Conclusion and discussion}

Based on the study of the conditions and problems of thinned teak in Thailand it's with findings that thinned teak or so called thinning for distance clearance being with small stems and can be sold at low price. The application for conversion of their forms are still not varied and inadmissible by the producers and consumers rendering the growers to receive the return on the growth relative low in the first stage where thinning is required, resulting the emergence of this research in seeking for market added value for thinned teak. On the verification of the mechanical property of thinned teak in comparison with teak from natural forest with age of over 30 years, it's found that the research result was with conclusion that it's negative with the hypothesis assumed i.e. thinned teak was with mechanical property different with teak from natural forest with age over 30 years old with the results of most of the tests were with findings that the values of the mechanical property of teak from natural forest with age over 30 years were more valuable than the values of the mechanical properties of thinned teak with exception on Standard Test Method for Tensile and Cleavage Test of Timber which thinned teak was with more value than teak from natural forest with age over 30 years old.

In respect of seeking for guidelines on market value added for thinned teak can be made by producing to use in the context of the design of household goods made of wood as the guide for resolution of problems and creation of artistic work pieces household goods made of wood which is consistent with the test result of thinned teak which is with prominence on tensile resistance and capable of producing for production and creation of household goods made of wood well, capable of helping emergence of economical investment, helping with environments and rural development and for the interest of promotion of teak plantation or forestry growth and resolution of problem on the exploitation from thinned teak as well as the promotion of Thailand teak industry to prosper and progress sustainably and can be competitive with foreign countries. Furthermore, this will also help communities residing in the rural areas to receive contribution and support on the development of artistic and handicraft work pieces and communal products for creation of identities and production of household goods products in the localities and capable of creation of work careers, including the development and creation of knowledge to conserve handicraft work pieces to inherit local/popular wisdoms to the next generations consistent with the national policy without prejudice to the surrounding conditions and environments.

\section{References}

1. Forest: Private Sector Forest Plantations, Office of Forest Growth Promotion, (2010)

2. Phusutsawaeng: Plantation and Management Economically for farmers and private sector, (2010), P.5-6.

3. Workman Standard MorYorThor (Thai) 2012541Standard Test Method for Compression Perpendicular to Grain Department of Public Works Ministry of Interior, (1998).

4. American Society of Testing Materials ASTM D 143:Standard Test Methods for Small Clear Specimens of Timber.

5. Workman Standard MorYorThor (Thai) 202-2541 (Standard Test Method for Compression Parallel to Grain) Department of Public Works Ministry of Interior, (1998).

6. Workman Standard MorYorThor (Thai) 203 - 2541 (Standard Test Methods for Direct Moisture Content Measurement of Wood) Department of Public Works Ministry of Interior, (1998).

7. Workman Standard MorYorThor (Thai) 2042541(Standard Test Method for Static Bending of 
Timber) Department of Public Works Ministry of Interior, (1998).

8. Workman Standard MorYorThor (Thai) 205 -2541 Standard Test Method for Tensile and Cleavage Test of Timber Department of Public Works Ministry of Interior, (1998).
9. Thai Industrial Standard TSI. 421-2525 Converted Wood: General Specifications, (1982).

10. Department of Public Works Ministry of Interior 207-2541 Standard Test Method for Specific Gravity to Grain, (1998). 